\title{
Monstrosity, Abjection and Europe in the War on Terror
}

\author{
Gaia Giuliani \\ Centre for Social Studies, University of Coimbra, Coimbra, Portugal
}

\section{Introduction}

The following reflection connects texts and contexts relevant to themes of abjection (Kristeva 1980), monstrosity, and the European take on the "War on Terror," whether the texts are those upholding national security discourses and risk management measures or the cultural materials forging the imaginary of the War. ${ }^{1,2}$ My argument is based on the research undertaken on the origins and transformations of anti-Muslim feelings from the foundation of Modern Christian Europe up to today, and specifically at the time of empires and afterwards, focusing on Britain and the US. I am referring to the debate on the relation between racism, anti-semitism and Islamophobia, the one between Islamophobia and colonialism, and finally the one on Islamophobia in postcolonial modernity. The historical and genealogical perspective these debates articulate is necessary for an exploration of the many nuances, be they naturalising or culturalist, that have characterised Islamophobia since 9/11. The first debate (e.g. Halliday 1999; Allen 2010; Malik 2010; Bravo López 2011; Esposito and Kalin 2011) explores overlaps and connected dynamics of anti-Semitism and Islamophobia in Europe, the Middle-East and the US. Nonetheless, my considerations about the genealogies and contextual transformation of "figures of race" stem from a conflation of Islamophobia with racism (on this topic see Sayyid and Vakil 2010; their reflection focuses on Islamophobic believes, behaviours and institutional patterns in the UK, and analyses it within the complex articulation of racialised diversities in a hegemonic white nation). This theoretical move is due to a conception of racism that sees it as the process of inferiorising naturalisation of certain subjects'

CONTACT Gaia Giuliani giuliani.gaia@gmail.com

${ }^{1}$ The research I present here builds on the conclusions of my book, Zombie, alieni e mutanti, Le paure dall'11 settembre a oggi (2016). A specific essay has also been dedicated to Lampedusa as a frontier: "The Colour(s) of Lampedusa," published in the volume Fortress Europe, Border Lampedusa. Migrations across the Mediterranean Sea in Cultural and Comparative Perspective, edited by Gabriele Proglio and Laura Odasso. London: Palgrave, forthcoming in 2016.

${ }^{2}$ By War on Terror I mean the war set of military operations in Africa and Middle East initiated by US President George Bush J. in 2002 and still ongoing under Obama's presidency (on continuities and differences between Bush and Obama's operations see Mullin 2011).

(c) 2016 The Center for Political Ecology 
bodily features and behaviours. This interpretation is enacted within a system of signs that identifies itself as superior. In Western modernity, this superior position is (openly or derivatively) described as white. Whiteness is thus a system of values, interpretations and practices, not a skin colour. As such it is racialised as superior. Within the same system of signs, race (as nonwhite as well as white) are floating signifiers (Hall 1997b). The difference between the two is constitutive: race constitutes whiteness as superior by contrast, the non-white being filled with inferiorising interpretations of a set of characteristics - for instance religion and its corresponding clothing, gestures, and social practices - of the racialised subject. Since the very beginning of Western modernity, Otherness has always been constructed as racialised, even when the modern (that is, positivist) theory of race did not yet exist. Colonial Otherness has been submitted, wiped out, and exploited within and outside Europe and its mobile borders. When it inhabited the outthere, it corresponded to the colonised. When it dwelled inside, it corresponded to the abject (the poor, the queer, the Huguenot, the mad, the peasant, the industrial worker). In some case, the latter has been interpreted as the greatest threat for Europe's internal order and treated like it needed to be exterminated. As a subject impossible to assimilate within Western rationalised modernity, it has become a monster.

Within this frame, my reflection draws in particular on research by the US and British postcolonial and black feminisms, whose focus has been the revision of citizenship - one that "diminishes (certain) human agencies" (Gilligan 2009) - engendered by feelings of fear and uncertainty and unprecedented Islamophobia (Furedi 2007; Butler 2009). In the US, Puar (2007) explored this revised model of citizenship in terms of a kind of nationalism that includes the white gay community against the enemies of the nation. These inclusive discourse and practice employ the gay community as the symbol of a secularised nation and sustain the narrative that sees migrants from Asia, Africa and the Middle-East as the nation's nemesis ("homonationalism"). In Europe, scholars analysed the same revised model of citizenship in terms of the post-modern re-articulation, through white feminism, of colonial discourses on "the civilising mission." They explored current re-articulations of a typically colonial discourse, which sees brown women as to be rescued by white women from brown men (see Spivak 1988; Burton 1990; Ho 2007; Navarro 2010; Syed and Ali 2011; Idliby 2014). They see it as corresponding with today's so-called emancipation of brown women through highly gendered and exploited (mostly domestic) labour (see Young 1990; Ahmed 2000; Tyler 2009; Anderson and Shutes 2014; Marchetti 2015). This (post-)colonial discourse operates a form of differential inclusion (Mezzadra and Neilson 2013) which excludes "dark-skinned men," considered as necessarily patriarchal, sexist, heterosexual, homophobic and violent, and includes their women exclusively as victims. In other cases, this revised citizenship 
symbolically excludes all Muslim and dark-skinned migrants, both men and women, coming from Muslim-dominated geographical areas, by virtue of a definition that sees them as incompatible with Western values.

These processes of exclusion and differential exclusion need to be read in parallel with the ongoing debate on the double-featured nature of contemporary Orientalism. This double-featured Orientalism sees not only a related paranoia about "culture clash" (Islamophobia), but also an appropriation of some aestheticised and fetishised aspects of Otherness (controllable and commodifiable cultural products such as food, music, and fashion; see Sharma and Sharma 2003; Tyler 2009). These processes also need to be read in the context of neocolonial practices of unveiling and of hyper-eroticisation and exoticisation of the Muslim female body (see, e.g. Yegenoglu 1998; Afshar, Aitken, and Franks 2005; Ahmed 2011).

\section{Monstruosity, Otherness and Abjection}

Building on these premises, the construction of the monstrous is discussed here as both a discourse and a practice connecting the internal abject (the French terrorist) and the external threat (the migrant/refugee that lands in Lampedusa or crosses the Eastern frontiers of Europe), conflating them in the unstable figure of the absolute Other. Monstrosity does not identify only the categories of people conceived as Other, but, more importantly, it identifies by contrast the unsaid, unspeakable feature of Europe as a profoundly racialised "imagined community" (Anderson 1982). The category of the absolute Other referred to here is a "figure," a fictional element of a hegemonic geography of signs that pretends to cancel stories of resistance and resilience. This absolute Other is also made of those stories against which it rearticulates and reproduces its bio-power and hegemonic narrative. I use this figure of the absolute Other (the monster) here to highlight a tension - that of the conflation of the internal abject and external threat - created by the co-working of material (governmental) and symbolic (discursive) devices. This figure and the tension it recalls manifest themselves as both the outcome of the symbolic labour of border control regimes and the potential scenario of non-hegemonic encounters between subalternities.

My thesis here is that the contemporary formation of a particular discourse conflating Islam, postcolonial migration and terrorism contributes to the construction of the European/national Self as middle-class, Christian and secular. This discourse continuously reproduces the Self through its Others by opposition. Monstrosity characterises Otherness, Otherness is apparently coincident with "alienness" to an alleged Western civilisation described as homogeneous and self-generated. However, if we look contextually and historically, we realise that "alienness" is something internal and as such coincides with abjection. 
Here I see abjection in line with Kristeva (1980) as a thing that "disturbs identity, system, order" but which forms an indispensable part of oneself. I see the "oneself" Kristeva refers to as the body politic, whether of the nation, Europe or the West (in line with Ahmed 2004, chap. 1). Abjection and monstrosity signal the Self's internal and external boundaries, establishing its identity. Abjection and monstrosity are the outcome of a hegemonic reading of geographies, individual and collective positionalities, and ideas of a Self and its Others that place the source of danger at specific intersections of colour, gender, class and cultural/religious lines. These lines are discursive constructions formed for and made "functional" (Hall 1997a) to a number of (often conflicting) power relations that re-centre Europe and the West in a Global History that excludes subaltern stories and subjectivities.

In line with post-human feminism, I build on the idea that monstrosity and the dichotomy between internal/external, Self/Other, legitimate violence/ terror have played a fundamental role in shaping, by opposition, ideas of authority, sovereignty and the State since the beginning of modernity, and that they continue to do so in the time of the War on Terror:

Monsters serve both to mark the fault-lines but also, subversively, to signal the fragility of ... boundaries [between humans and almost-humans]. They are truly monstrous ... in their simultaneous demonstration and destabilization of the demarcations by which cultures have separated nature from artifice, human from non-human, normal from pathological.... In their capacity to show up the leakiness of bodily boundaries ... this emergent array of hybrid creatures are arguably "monstrous" not so much in the horror they evoke but in their exposure of the redundancy and instability of the ontological hygiene of the human subject. (Graham 2002, 12, emphasis added)

Here the concept of "ontological hygiene of the human subject" functions at both a bodily and a social level. The (human) body as well as the body politic are in danger and need to be eugenically preserved from hordes of aliens that, like a mortal disease, have to be eradicated from the healthy corpus of European nations. The apocalypse is not far to come - hordes of barbarians have already devastated the heart of the West and its symbols: the Twin Towers, the London underground, Madrid's train station and the most important postcolonial cities in the West.

So hygiene plays for the human body the role that twentieth-century negative eugenics played for the social body, offering a set of medical/surgical devices to cleanse the body of the nation from corrupting bodies. Hygieneeugenics is supposed to remove those corrupting bodies, but at the same time it recasts them as abject over and over again, as their abjection is necessary to legitimise the State's power. This mechanism corresponds to the process that, following the slaughter at Charlie Hebdo and the terrorist attacks that targeted Bataclan, Le carillon, Petit Cambodge and the Stadium, has brought the sovereign subject, its French and European representatives, 
to reconfigure the borders of the "imagined community." The symbolic borders that are now drawn mark the three attackers at Charlie Hebdo Saïd Kouachi, born in 1980, and his cousin Chérif Kouachi, born in 1982, two young French-Algerians raised in Gennevilliers, and their accomplice, Amedy Coulibaly, a 32-year-old born in Juvisy-sur-Orge - as aliens. Their stories have not been explored as part of the history of contemporary French society. Neither has that of the terrorist ringleader Abdelhamid Abaaoud, of the Paris attacks in November 2015, who was a Belgian-Moroccan citizen. Abaaoud has been described as entering Europe with the flood of migrants and refugees - as if he and every migrant/refugee were embodying a fanatic Islam that trespasses European borders for the first time, and as if fanaticism were the only modality of Islam. The territorial alienation (he was raised in Belgium, but then went back "there" - to reach Da'esh in Syria) that is implied in the phrase "penetrating Europe," helped by the migrants crisis, externalises him as if he had no story in Europe before, as if he was the product of an alien force that had reinstalled him twice amongst us (when he was a kid and as an adult terrorist; see Allen and Charlton 2016).

The border is played also internally through the distinction between good and bad migrant/refugee, as an internal border that confirms and sustains the geopolitical separation between the Good West and its Bad Others. The good migrants/refugees have been critically defined by Chow (1998) as idealised Other[s], that is, good Muslim men and women who claim their belonging to the Western nation of arrival after a migratory process, embracing its social hierarchies and white privilege. As Sanjay Sharma and Ashwani Sharma wrote in their paragraph allusively titled "White Skin, Oriental Masks," they are "necessary to sustain the hegemonic positionality of Whiteness, through a narcissistic mode of racial authority and power dependent upon a knowable and controllable Other" $(2003,307)$.

The good abject, ontologically alien, must remain trustful and reliable for it to be deemed possible for her/him to integrate (though never fully). The domestication of the alien needs to be continuously reinstated, and nonetheless depicted as not fully controllable. This explains why, in the case of the Paris attacks, the internal Others/monsters who carried out the attacks have been broadly portrayed as naturally barbaric, unable to be absorbed by civilisation. As models of failed assimilation, these men - necessarily men - were supposedly imbibed with the quintessential French values of liberté, egalité, fraternité. But they clearly could not resist their own nature; they reverted to barbarity as if pushed by an unstoppable force. As a monster, the Islamic terrorist will always be a dormant cannibal ${ }^{3}$ hidden in the folds of normal

\footnotetext{
${ }^{3}$ The use of the cannibal metaphor in this context comes from colonial times and refers to the monstrous nature of "backward populations" colonised in the Pacific, Africa and South America. It refers to the
} 
family lives, and will eventually wake up. The only solution is his physical and symbolic erasure through hygiene-eugenics.

His presence is, in fact, a very troublesome element which reveals the porosity and instability of official history and national identity. This element shows how, within a postcolonial context, the right to feel equal, free and brotherly is reserved solely for a specific hegemonic subject, and that violence could be conceived as a way to regain the voice often taken away from subalterns by hegemonic culture. The presence of an internal Other discloses the national community's unevenness and its internal contradictions, including the persistence of "colonial fractures" (Blanchard, Bancel, and Lemaire 2005), and reveals French anti-Islamism as a product of a "secularism" that it is supposed to be neutral but is fundamentally Christian and hegemonically white (Butler 2008, 1-23; see also Balibar 2004a, 2004b; Mbembe 2005; Delphy 2008, 2010). Finally, the construct of a presence of an internal Other shows how in the case of the 2015 attacks in Paris the present cannot be isolated from the past and the events' location cannot be separated from its global situatedness.

The internal Other makes the dichotomy between fit/unfit for civilisation, good/bad, true/false, us/them very unstable. Indeed, the hegemonic narrative of the attack downplayed the fact that many of the victims were also not white. For example, Ahmed Merabet, the non-white French Muslim policeman shot to death by the attackers of Charlie Hebdo offices, cannot belong to the monstrous because he is, in fact, a "victim" of terrorist violence. The victim as such is whitened, purged of his otherness because of his sacrifice for the Nation's integrity. The non-white victims are thus re-appropriated, while terrorists are made into aliens. The territorial alienation that I have described in the case of the attackers in Paris and Brussels, as well as the appropriation (symbolic and physical absorption in the body of the nation) of the good Other are functional to a figuration of the nation as a self-consistent and self-reflexive entity devoid of internal diversity, conflicts and disparities.

Islam, a constant presence in Europe for at least 1300 years, is increasingly becoming a black hole in the discourse on post-9/11 European terrorist attacks. Islam functions as the gate through which monsters reach our world. Islam figures in many discourses as an incubator of Evil that releases aliens ready to kill, to exterminate, as if it could hide the internal contradictions and regimes of violence that set Europe apart.

The fiction of a peaceful and harmonious Western/European society, sharing common Christian "values" and notions of State and "welfare," is

construct of a black barbarian (Africa) and of the "dormant terrorist" (Muslim migrants), both groups coming to "cannibalise" the West, making it subaltern or even disappear. I thus deploy this notion with two very different meanings in order to represent both fears of (European/Western) disaster in white (post-)colonial minds (see Giuliani 2016a). 
revealed as soon as Europe needs to be presented as a single political/historical entity. Think about recent European nations' disagreements on military interventions in the Balkans (1990s) and in the Middle-East (1990-2010s), not to mention European Union's internal disagreement on the entry of Turkey (as a Muslim country) into the Union. Think also about the disagreement among European Union countries on anti-crisis measures after 2008 and, more recently, on a common European Union approach to both the Arab crisis and the Syrian refugees' quest for asylum. ${ }^{4}$ In the case of refugees trespassing Eastern European borders, the disagreement and ambiguity internal to the European Union had first seen European countries as warm-hearted and supportive of refugees, then as determined in signing an agreement with Turkish Prime minister Erdogan designed to stop them at the Turkish frontier. This turnaround is expressive of the mounting of anti-refugee and islamophobic feelings (Kingsley 2016). In early January 2016, these same feelings led the media and state officials to point to Muslim refugees as perpetrators of (brown) male sexual assaults on (white) women in Cologne (New Year's Eve 2016). ${ }^{5}$

Indeed, a history of constant abuse of minorities (mostly Roma peoples and Muslims) constellates the national history of every European country. Europe, and particularly the European Union, has been constructed as a cultural, social and political entity after the Second World War, founded on the promise that internal war and internal genocide would not happen again. This refusal of internal conflict does not, however, induce further reflection on the extent to which certain assumptions of the European imagined community are still unavoidably and willingly shaped by a monolingual address (Sakai 1997) ${ }^{6}$ inherent to the West's enduring colonial mentality. This monolingual address hides the inherent feature of the European imagined community, namely that it is shaped by a set of internal borders which reproduce a system of discriminations and "differential inclusions," and fix the level of exploitability and abjection of its subjects (Mezzadra and Neilson 2013). Although the Holocaust can be said to have found its premises in colonial genocide (in Namibia, by German colonisers, but also in Libya, by Italian colonisers, as well as in South America and Australia) and to be a product

\footnotetext{
${ }^{4}$ Facing the crisis, European Union members acted in very disparate ways. Hungary closed its frontiers, while Germany at the beginning showed a quite welcoming approach (although compromised by declarations by Prime Minister Angela Merkel on Germany selecting refugees on the base of their skills). Today Austria is building a barrier along its border with Italy, and so is Slovakia along its southern border. Meanwhile Greek islanders (Lesbos inhabitants in particular) show evident solidarity with the refugees, despite the risks it entails (see Akkoc 2015).

${ }^{5}$ Panic broke out after the supposedly mass "monstrous" sexual attacks carried out by brown men on white women during the celebrations of New Year's Eve in Cologne (Germany). On what happened during the attacks see McGuinness 2016 and Mortimer 2016.

${ }^{6}$ By monolingual Sakai means an address which reduces all diversities in language and culture to a homogeneous system of linguistic signs, and which interprets, purges and absorbs only the elements considered possible to be integrated while maintaining hegemony.
} 
of European modernity, as Bauman (1989) has observed, Europe avoids fostering public awareness on what sustains postcolonial violence.

Two worlds of globalisation are represented through risk practice in the War on Terror: one populated by legitimate and civilised groups whose normalised patterns of financial, leisure or business behaviours are to be secured; and another populated by illegitimate and uncivilised persons whose suspicious patterns of behaviour are to be targeted and apprehended. (Amoore and De Goede 2008, 5-6)

This dichotomy builds a pattern for interpreting the events that happen in what is conceived to be the external world of the alien - the Other of the West - where armed fundamentalism claims far more victims than in Europe: apparently we do not care about what happens on the monsters" planet (where many European states invest lots of money in oil extraction, military industry and sweatshop production) because victims over there are expendable, as described by Talal Asad. In the same hours as the Charlie Hebdo attack took place, Boko Haram jihad fighters were massacring thousands of people in Baga, Nigeria, and in the city's 16 surrounding villages. A few months later, on 2 April, armed fundamentalists put 150 students to death in a Kenyan high school (Levs and Holly 2015). After the attack in November a continuous bombing and killing perpetrated by Da'esh in Syria and North Africa (Tunisia), cost the lives of hundreds of people, mostly civilians. In all these cases, the terrorists did not attack the West, and as such the massacres are addressed as a matter of "disaster management and humanitarian assistance." Disaster management, along with reparation, is today one of the fields where the new Western discourse on "deservedness" is forged, involving the selection of those who deserve help and public consideration from the West and those who do not.

This way of interpreting the post-9/11 geopolitical landscape - as shaped by a dichotomous idea of two separate worlds - is described by Asad (2007) and Mbembe (2003) as driven by neocolonial attitudes. Their vision problematises Foucault's opposition between the two different modern biopolitics, namely between the disciplining strategy of "killing/letting live" (sovereignty) and "fostering/disallowing life" (biopolitics). Asad and Mbembe argue that neocolonial situations see the coexistence of both aspects and are based on the fundamentally colonial attitude of classifying Others as "expendable." The neocolonial lack of responsibility for the victims is structural to a War of the Worlds setting, where the enemy is not addressed as a nation (that is, an entity deserving of all rights denoted by international law), but as a monster. Monsters are deprived of the right to mourn which is the prerogative of the "subject of right." The "killable" Other is the product of a conception of "life" within the "frame of war" (Butler 2009), that is, the Other is shaped by both the securitisation and the criminalisation that come with the "small colonial wars" (Asad 2007) essential to the spread of freedom, progress and 
peace. Therefore, insofar as military interventions by Western powers continue this colonial tradition, it should be evident that their primary aim is not the protection of life as such but the construction and encouragement of specific kinds of human subjects and the outlawing of all others.

\section{Small Colonial Wars and Proximate Monstrosity}

In the frame of those "small colonial wars," transnational migrants are among those paying the costs of a eugenic interpretation of society that externalises like in the case of Paris attacks - its own foreclosed colonial memories and considers such acts the result of external terrorism.

This is the case of the Lampedusa mass drowning on 3 October 2013 - a "let die" strategy that has no end and that shortly afterwards caused the death of 900 people offshore Malta (11 October 2013). The nearly 400 victims were presented by Italian and European Union institutions as the result of a disaster, as victims of illegal human trafficking, of the uncontrollable forces of the sea, of destiny, or of bad luck. In the subsequent months, reports of drownings appeared non-stop ("Naufragio a sud della Sicilia ..." 2015; "Naufragio Lampedusa ..." 2015). On 19 April 2015, 800 people went missing off the shore of Malta (Sim 2015; "Immigrati ..." 2015). Over the same months, the Syrian refugee crisis is still depicted as something for which Europe bears no responsibility, as hundreds of people leave Syria by sea or by land, cutting across Turkey or reaching Greece by boat, getting offshore and dying or, as survivors, crossing Eastern European borders, getting stopped, beaten up, encamped along borders and now deported back to Turkey. There is no reflection on the causes of those deaths or a sense of human solidarity with the survivors. In the case of Lampedusa, the funerals were celebrated in Agrigento, far away from survivors, who are granted no recognition, nor any freedom of movement or right to stay. The dead can be symbolically included, but those who are alive are still conceived of as dangerous monsters. They cannot even attend their relatives' and friends' funerals. They cannot mourn them. They are there to be mastered, controlled, checked by border agencies, homeland security and police.

The inferiorisation/animalisation of the abject occurred with the very first examples of bodily measurements within colonial and slavery discourses, particularly as part of positivism. Today the post/neocolonial nature of bodily measurements, or biometrics (see Bigo 2002; Fekete 2004; Pugliese 2010, 2013), as inferiorising systems that diminish racialised people's agency, is evidently enacted by contemporary border protection systems:

[In border protection] manuals, the human population is envisaged as "a zoo." Human beings are divided into five groups: sheep, goats, wolves, lambs and chameleons.... This is not because animal life has been elevated to the level of human life. Rather, it is because, in the logic of biometrics, "life" is 
nothing more than a functional attribute of the object that is key to the technology's efficiency. (Epstein 2008, 185)

The supposed condition of permanent crisis determines and is said to be determined by constant migration flows and by an alleged "persistent risk" of a potential transformation of "risky bodies," meaning old and new migrants and their offspring, into terrorist cells. This potentiality allows and justifies the re-allocation of power to the State and reinforces its power to set a hierarchy among people, nationally and internationally, along colour, gender, religious and class lines. In fact, the definition of risky body comprises two different meanings: that of a body at risk, and that of a body of risk (Salerno 2016). In the same boat are bodies at risk and bodies of the risks, that is, de-historicised bodies conceived either as victims of a disaster or as threats and/or vectors of disaster into European space. This iconography collapses the gendered victimisation of women and children and the criminalisation of young and adult men that cross the Mediterranean into an idea of postcolonial migrants as threatening - while at the same time revealing - postcolonial global inequalities. This double (gendered) feature of the risky body is confirmed by securitisation studies (see Wæver et al. 1993; Bigo 2002; Huysmans 2006), which have shown how migration can be turned into a security issue and how the humanitarian rhetoric can help sustain it as an essential element of governmentality, particularly regarding the government of human mobility (Bigo 2002; Agier 2008). My analysis builds on these results to move a step forward towards a conception of "bodies at risk" and "bodies of risk" as jointly infused with a dormant barbarism that makes the victim into a potential monster. Victimhood can thus always be reversed into inherent danger, and in so doing security measures, manuals and practices ontologise, de-politicise and de-historicise a condition of the migrant/ refugee. The ontologised condition of the risky body is constituted by both a notion of inferiority and the idea of its "illegitimate" mobility. By ontology of inferiority I mean the outcome of a discourse that:

concealing the migrant's history, by abstracting the migrant from his or her immediate social context, the migrant can then be repositioned outside modernity and into what McClintock (1995) calls "anachronistic space\&rsquo;: a space imagined as "inherently out of place in the historical time of modernity. ..." In colonial thought this has normally meant casting the Other as prehistoric, savage, and atavistic ... the Other is displaced onto a rather unique posterior, future-conditional time.... Not an ontologically discrete future timespace that comes after the present in an ordered chronology, but one situated between present and future in which the future is already present in the present, albeit in virtual form. ${ }^{7}$ (Baldwin 2013, 1483)

\footnotetext{
7Unlike Baldwin, I argue that the "in-betweenness" of the migrants' condition is not limited to the climatechange migrant. I maintain that this condition is also experienced by other migrants and by refugees who pose a threat of bringing disaster (ecological catastrophes as well as warfare) into Fortress Europe.
} 
In turn, by illegitimate mobility I mean the idea that racialised Others, escaping the control of both local state institutions and international organisations that want them sedentary (Bakewell 2008; Castles 2010; Bettini 2013), make themselves into a nuisance. I also mean the idea that in trying to enter European space, they violate the ban imposed on (post-)colonial subalterns to prevent them from crossing the border that constitutes them as subalterns. In such a way, the ontologised construction of the figure of the migrant/ refugee both threatens and reconfirms which society it is that must be defended (Foucault 2003). In the frame of the War on Terror, the charge of terror reinforces this ontology, adding to its picture the ferocity of blind fanaticism.

Along the ontologised figure of the risky body the line is drawn that identifies who can be considered "torturable" and "killable," "excluded," "included/ absorbed," "partially included" within a citizenship (as an "encamped space" [Gilroy 2000, 83] defined by social and political rights and reproduced by its own "deportation regime" [De Genova and Peutz 2010]). This classification is always and necessarily defined by constructions of class, gender and sexuality. The government over the population is set along the colour/gender lines that design the space of citizenship, and is implemented through a range of practices that discipline and reproduce the life and death of both "normal" people (those who must be defended) and risky bodies. In a geopolitical landscape that connects, since 9/11, overseas scenarios of the War on Terror to homeland security and social control, these practices also set the levels of violence that sovereign institutions (the state and its army, police and government apparatuses, but also international organisations' armies and intelligence) should invest in the "management" of risk. If in Iraq, Afghanistan, Libya and Syria the state will use a specific type and amount of violence, it will use, within its own borders, other rankings and devices, according to the intersectional position (and the legal status of citizen vs refugee/migrant) occupied by the potential or actual perpetrator.

Nonetheless, what bridges the external use of violence and internal hygiene/eugenics is the intersecting constructions and tensions between Otherness and monstrosity that threaten and confirm the persistence of Western practices of white hegemonic citizenship. The representation of the risky body - whose position is both internal and external - as abject and inherently monstrous, builds and reinforces the material border, giving to its fictitiousness an ontological allure, as if the society inscribed within state borders was historically, culturally and socially homogenous.

Yet, just as they construct the Self as such, so symbolic and material borders segment space, revealing how supposedly universal rights are context- and position-related, and also disclosing the illegitimacy of resilience, resistance and violence against inequalities within and across borders. The diminished agency of internal and external Others inherent to the functioning 
of a border regime is evidenced in the nullifying of the "encounter" between the population of Lampedusa and Lesbos (where many Syrian refugees land), and incoming migrants and refugees - especially when it appears inconsistent with European Union decisions. Inhabitants are treated as silent spectators or hidden accomplices. Evidence of Islander (Lampedusians and Lesbosians) resistance and resilience against rules, military apparatuses, and symbolic constructions legitimising and reproducing a polarised idea of Mediterranean and global geographies cannot be silenced, but can be nullified. Nullification occurs through a discursive process that assumes solidarity as something nonpolitical, but pertinent to the sphere of infantilised, inferiorised emotions or faith (as evidenced by the status quo in current systems of border control and Pope Francis I's speeches in Lampedusa and Lesbos in April 2016). Islanders are prevented from rescuing incoming refugees and face criminal charges used to punish facilitators of illegal immigration. In the modus operandi of the "encounter" imposed on Islanders by the law, their deontology as seamen and islanders - which drives them to help and rescue those who end up in trouble offshore - and their freedom of choice are nullified. As borderised agents they are apparently left with no subjectivity in a land that is not theirs anymore.

Lampedusa, Lesbos and their populations are made into a particular "governmental object" due to the peculiar position they occupy within the space of the nation. This position is loaded with racial stereotypes ${ }^{8}$ that can be traced back to when Italy and Greece were created as nations and the South was labelled as culturally discontinuous, socially impossible to master and racially different (see Giuliani 2013 for Italy; Tziovas 2009 and Lauth Bacas 2005 for Greece).Theirs is an in-between positionality, one that sees the two islands as part of the state and Europe, and at the same time made by both into de-subjectified objects of governmentality. Being stages where the border is set, Islanders are made into mere devices for the global regime of migration control (Cuttitta 2014, 206). Lampedusa and Lesbos affirm the understanding of the colonial world as structured in a multiple and internally conflicting set of complicities with and resistances to colonial power and dominance.

\section{Resilience, Resistance and Violence}

Material and legal violence against the monster is always legitimate. On the contrary, the monster's resistance, resilience and violence are by definition never legitimate. As a threat to Europe's internal order, the Other's violent response to borderising corresponds to the fulfilment of the "figure of race" $\mathrm{s} / \mathrm{he}$ embodies, and of deepest fears of monstrous invasion and disorder:

${ }^{8}$ Since the seventeenth century, Southerners and Islanders of Mediterranean European countries have been considered as having black blood from "Camitic and Semitic populations" (Dainotto 2007). 
Grusin (2010) conceptualises premediation as a form of reasoning specific to American media landscapes after 9/11, but premediation also has explanatory value beyond these landscapes. For example, it has been used to characterise the governing logics of other risk landscapes, including the War on Terror ... and climate change ... According to Grusin, then, what matters in premediative logic is not whether the anticipated futures are correct. Premediation is not a form of predictive reasoning. Rather, what matters is that by proliferating possible futures in advance of their occurring, premediation allows for the future to become actionable in the present... for an action to be taken in the present based on a range of premediated futures. (Baldwin 2016, 82)

But to premeditate the future means to read it through the lens of a knowledge which is already acquired and deeply connected to a long-lasting modern conception of the world as divided between civilisation and barbarity. So, the violent subjectivity of the Other whose rage bursts out at the frontier, in Paris as well as Europe's urban outskirts or in the Italian Identification and Expulsion Centres (set by the Turco-Napolitano Law n. 40/1998), does not correspond just to the "actionability" (Baldwin 2016) of the future in the present, but also to the fulfilment in the present of a memory of the future. The future memory of Europe overwhelmed by hordes of risky bodies and their terrorising charge corresponds to a memory of colonial fear (an apocalyptic scenario envisaged in colonial times) of barbarism stopping or reversing civilisation - both within the nation and outside, in its colonial dimension - which has always been projected into a future and which now has become premeditated.

In the cases of Lampedusa and Lesbos, the two islands and their inhabitants have for long been described as liminal to symbolic citizenship, situated at the margins of a Nation-State's territory, institutions and society. As objects of the violence of bio-power, their marginality was inherent to the internally colonial nation-building processes, functional to an ontology of the nation identified along precise class, race, gender, sexuality and regional axes. As lands "for fishermen" and emigration (during the last 50 years Lampedusians and Lesboans increasingly migrated inland and abroad), in the discourse on mass illegal immigration Lampedusa and Lesbos figure as the South of the South (islands placed at the South of national inland South). During the migrant/refugee emergency, they have been depicted as spots inhabited by uncivilised "poor" people barely able to profit from the islands' beauties (the tourism sector has been only very recently developed), too "soft-hearted" to cope with the dangers and challenges of illegal boat-people landings.

Fanon (1967) surmised that the most offensive feature of normative thinking within colonial discourse was not just to state its own benevolence, but also to assert the physical and moral necessity of a guide for colonised peoples, dooming them to perennial infantilisation. This infantilisation of the internal abject and the victimisation of some of the boat-people according to gender, age, and skin colour and the casting of the male abject (the one who 
comes and stays as an actual or a potential terrorist threat) as monsters are two discourses which now lie at the base of a precise idea of the European/ national Self. In Paris and in many peripheries of the French metropoles, there are emerging deep critiques of French colonialism and the way postcolonial France comes to terms with its colonial legacies and violence (e.g. Djouder 2006; Balibar 2007; Sassu 2011). From the 2005 revolts to those rebellions that, with less commotion, occur every day in suburban areas, the context engendering violence is anything but sporadic. In Lampedusa and mainland Italy, as well as on the Eastern frontier through which Syrian, Afghan and Iraqi refugees try to reach Europe, there are incessant revolts against border control measures, convictions in the Identification and Expulsion Centres, racist behaviour in law enforcement and resurgence in migrants' subjectivity. This affirmative violence - the "generative violence" (Fanon 1963) of the revolt against colonial and postcolonial practices enacted by racialised subjects - as much as the destructive violence of terrorist attacks need to be explored in depth. To analyse genealogies and representations of that violence, it is necessary to outline those semantic fields around which the We starts to solidify in this new phase of the War on Terror. It is necessary to valorise such forms of resilience, resistance and solidarity against the biopolitics of borderising and which is increasingly rising in a South-South geography of mobility (Gandhi 2006).

\begin{abstract}
Today borders are not merely geographical margins or territorial edges. They are rather complex social institutions, which are marked by tensions between practices of border reinforcement and border crossing [...]. They play a key role in producing the times and spaces of global capitalism. But they also shape the struggles that rise up within and against these times and spaces - struggles which often allude problematically, but in rich and determinate ways, to the abolition of borders themselves. (Mezzadra and Neilson 2013, 3)
\end{abstract}

If I align myself to the idea that "the ethics of hospitality and welcoming [can't] shift the social relation of capital that is invested in every border in contemporary world" (Mezzadra and Neilson 2013, chap. 10), I subscribe to the view that the "being-in-common" of the internal and external abject allows for a grammar of resistance that brings to light the "common" - the sea, the land, the islands - beyond, under and against borders.

\title{
Acknowledgements
}

The author is grateful to Profs Sandro Mezzadra (University of Bologna), Lars Jensen (Roskilde University), and InteRGRace members, Drs Tatiana Petrovich Njegosh (University of Macerata) and Daniele Salerno (University of Bologna) for their revisions and insightful comments.

\section{Disclosure Statement}

No potential conflict of interest was reported by the author. 


\section{Funding}

This work was funded by the Portuguese Foundation for Science and Technology.

\section{References}

Afshar, Halem, Rob Aitken, and Myfanwy Franks. 2005. "Feminisms, Islamophobia and Identities.” Political Studies 53 (2): 262-283. doi:10.1111/j.1467-9248.2005. 00528.x.

Agier, Michel. 2008. Gérer les indésirables. Des camps des réfugiés au gouvernement humanitaire. Paris: Flammarion.

Ahmed, Leila. 2011. A Quiet Revolution: The Veil's Resurgence, from the Middle East to America. New Haven: Yale University Press.

Ahmed, Sara. 2000. Strange Encounters: Embodied Others in Postcoloniality. London: Routledge.

Ahmed, Sara. 2004. The Politics of Emotions. New York: Routledge.

Akkoc, Raziye. 2015. "Refugee Crisis: Europe's Borders Unravelling as Austria and Slovakia Impose Frontier Controls." The Telegraph, September 14. www. telegraph.co.uk/news/worldnews/europe/eu/11863246/Refugee-crisis-EUministers-Germany-border-control-Austria-army-live.html.

Allen, Chris. 2010. Islamophobia. Farnham: Ashgate.

Allen, Peter, and Corey Charlton. 2016. "Paris Terrorist Ringleader Bragged He Entered France among a Group of 90 Jihadis and Claimed the Migrant Crisis Had Made it Easy for Them to Travel Freely across Europe." Daily Mail, February 4. http://www.dailymail.co.uk/news/article-3431479/Paris-terroristringleader-bragged-migrant-crisis-easy-Islamists-travel-freely-Europe-revealswoman-led-police-him.html.

Amoore, Louise, and Marieke De Goede. 2008. "Introduction." In Risk and the War on Terror, edited by Louise Amoore and Marieke De Goede, 5-19. New York: Routledge.

Anderson, Benedict. 1982. Imagined Communities. London: Verso.

Anderson, Bridget, and Isabel Shutes, eds. 2014. Care and Migrant Labour: Theory, Policy and Politics. London: Palgrave.

Asad, Talal. 2007. On Suicide Bombing. New York: Columbia University Press.

Bakewell, Oliver. 2008. "'Keeping Them in Their Place': The Ambivalent Relationship Between Development and Migration in Africa." Third World Quarterly 29 (7): 1341-1358. doi:10.1080/01436590802386492.

Baldwin, Andrew. 2013. "Racialisation and the Figure of the Climate-Change Migrant.” Environment and Planning A 45: 1474-1490. doi:10.1068/a45388.

Baldwin, Andrew. 2016. "Premediation and White Affect: Climate Change and Migration in Critical Perspective." Transactions 41: 78-90. doi:10.1111/tran.12106.

Balibar, Étienne. 2004a. Nous, citoyens d'Europe? Les frontières, l'État, le peuple. Paris: La Décourverte.

Balibar, Étienne. 2004b. “Dissonances Within Laïcité.” Constellations 11 (3): 353-367. doi:10.1111/j.1351-0487.2004.00382.x.

Balibar, Étienne. 2007. “Uprising in the Banlieue.” Constellations 14 (1): 47-71. doi:10. 1111/j.1467-8675.2007.00422.x.

Bauman, Zygmunt. 1989. Modernity and Holocaust. Ithaca, NY: Cornell University Press. 
Bettini, Giovanni. 2013. "Climate Barbarians at the Gate? A Critique of Apocalyptic Narratives on 'Climate Refugees."' Geoforum 45: 63-72. doi:10.1016/j.geoforum. 2012.09.009.

Bigo, Didier. 2002. "Security and Immigration: Toward a Critique of the Governmentality of Unease." Alternatives: Global, Local, Political 27 (1): 63-92. doi:10.1177/03043754020270S105.

Blanchard, Pascal, Nicolas Bancel, and Sandrine Lemaire, eds. 2005. La Fracture Coloniale: La Société Française au Prisme de l'Héritage Colonial. Paris: Gallimard.

Bravo López, Fernando. 2011. "Towards a Definition of Islamophobia: Approximations of the Early Twentieth Century." Ethnic and Racial Studies 34 (4): 556-573. doi:10.1080/01419870.2010.528440.

Burton, Antoinette M. 1990. “The White Woman's Burden: British Feminists and the Indian Woman, 1865-1915.” Women's Studies International Forum 13 (4): 295.

Butler, Judith. 2008. "Sexual Politics, Torture, and Secular Time." The British Journal of Sociology 59 (1): 1-23. doi:10.1111/j.1468-4446.2007.00176.x.

Butler, Judith. 2009. Frames of War: When Is Life Grievable? New York: Verso.

Castles, Stephen. 2010. "Understanding Global Migration: A Social Transformation Perspective." Journal of Ethnic and Migration Studies 36 (10): 1565-1586. doi:10. 1080/1369183X.2010.489381.

Chow, Rey. 1998. Ethics after Idealism: Theory, Culture, Ethnicity, Reading. Indianapolis: Indiana University Press.

Cuttitta, Paolo. 2014. “'Borderizing' the Island Setting and Narratives of the Lampedusa 'Border Play." ACME: An International E-Journal for Critical Geographies 13 (2): 196-219. doi:10.1007/s12134-014-0410-0.

Dainotto, Roberto. 2007. Europe (in Theory). Durham: Duke University Press.

De Genova, Nicholas, and Nathalie Peutz, eds. 2010. The Deportation Regime: Sovereignty, Space and the Freedom of Movement. Durham: Duke University Press.

Delphy, Christine. 2008. Classer, dominer. Qui sont 'les autres'? Paris: Éditions La Fabrique.

Delphy, Christine. 2010. Un universalisme si particulier. Féminisme et exception française (1980-2010). Paris: Syllepse.

Djouder, Ahmed. 2006. Désintégration. Paris: Édition Stock.

Epstein, Charlotte. 2008. "Embodying Risk: Using Biometrics to Protect the Borders." In Risk and the War on Terror, edited by Louise Amoore and Marieke De Goede, 178-193. New York: Routledge.

Esposito, John L., and Ibrahim Kalin, eds. 2011. Islamophobia: The Challenge of Pluralism in the 21st Century. Oxford: Oxford University Press.

Fanon, Frantz. 1963. The Wretched of the Earth. New York: Grove Press.

Fanon, Frantz. 1967. Black Skin, White Masks. New York: Grove Press.

Fekete, Liz. 2004. "Anti-Muslim Racism and the European Security State." Race and Class 46 (1): 3-29. doi:10.1177/0306396804045512.

Foucault, Michel. 2003. Society Must Be Defended: Lectures at the Collège de France, 1975-76, edited by Mauro Bertani and Alessandro Fontana. Translated by David Macey. New York: Picador.

Furedi, Frank. 2007. Invitation to Terror: The Expanding Empire of the Unknown. London: Continuum.

Gandhi, Leila. 2006. Affective Communities: Anticolonial Thought, Fin-de-siecle Radicalism, and the Politics of Friendship. Durham: Duke University Press. 
Gilligan, Chris. 2009. "Insecurity and Community Relations." In Community, Citizenship, and the 'War on Terror': Security and Insecurity, edited by Patricia Noxolo and Jef Huysmans, 32-50. London: Palgrave Macmillan.

Gilroy, Paul. 2000. Against Race: Imagining Political Culture Beyond the Color Line. Cambridge: Harvard University Press.

Giuliani, Gaia. 2013. "L'italiano negro. La bianchezza degli italiani dall'Unità al Fascismo." In Bianco e nero. Storia dell'identità razziale degli italiani, edited by Gaia Giuliani and Cristina Lombari-Diop, 21-66. Firenze-Milano: Le MonnierMondadori Education.

Giuliani, Gaia. 2016a. Zombie, alieni e mutanti. Le paure dall'11 settembre a oggi. Firenze-Milano: Le Monnier/Mondadori Education.

Giuliani, Gaia. 2016b. “The Colour(s) of Lampedusa.” In Fortress Europe, Border Lampedusa. Migrations Across the Mediterranean Sea in Cultural and Comparative Perspective, edited by G. Proglio and L. Odasso. London: Palgrave.

Graham, Elaine L. 2002. Representations of the Post/Human: Monsters, Aliens and Others in Popular Culture. New Brunswick: Rutgers.

Grusin, Richard. 2010. Premediation: Affect and Mediality After 9/11. London: Palgrave.

Hall, Stuart. 1997a. "The Spectacle of the 'Other."' In Representation: Cultural Representations and Signifying Practices, 223-290. Milton Keynes: Open University Press.

Hall, Stuart. 1997b. Race: The Floating Signifier. Lecture by and interview with Stuart Hall by Sut Jally. DVD. Northampton, MA: Media Education Foundation.

Halliday, Fred. 1999. “'Islamophobia' Reconsidered.” Ethnic and Racial Studies 22 (5): 892-902. doi:10.1080/014198799329305.

Ho, Christina. 2007. "Muslim Women's New Defenders: Women's Rights, Nationalism and Islamophobia in Contemporary Australia." Women's Studies International Forum 30 (4): 290-298. doi:10.1016/j.wsif.2007.05.002.

Huysmans, Jeff. 2006. The Politics of Insecurity: Fear, Migration and Asylum in the $E U$. London: Routledge.

Kingsley, Patrick. 2016. "Refugee Crisis: What Does the EU's Deal with Turkey Mean?" The Guardian, March 18. http://www.theguardian.com/world/2016/mar/ 18/eu-deal-turkey-migrants-refugees-q-and-a.

Kristeva, Julia. 1980. Pouvoirs de l'horreur: Essai sur l'abjection. Paris: Édition du Seuil. Idliby, Rnya T. 2014. Burqas, Baseball, and Apple Pie: Being Muslim in America. London: Palgrave Macmillan.

"Immigrati, venti anni di naufragi e tragedie nel Canale di Sicilia." 2015. laRepubblica. it, April 20. http://palermo.repubblica.it/cronaca/2015/04/19/news/immigrati_ oltre_dieci_anni_di_naufragi_e_tragedie_nel_canale_di_sicilia-112317922/.

Lauth Bacas, Jutta. 2005. "Mechanism of Boundary Construction on the GreekTurkish Maritime Border." In Culture and Power at the Edges of the State: National Support and Subversion in European Border Regions, edited by Thomas M. Wilson and Hastings Donnan, 55-60. Munster: Verlag.

Levs, Josh, and Holly Yan. 2015. "147 Dead, Islamist Gunmen Killed after Attack at Kenya College.” CNN, April 2. http://edition.cnn.com/2015/04/02/africa/kenyauniversity-attack/.

Malik, Maleiha. ed. 2010. Anti-Muslim Prejudice: Past and Present. London: Routledge.

Marchetti, Sabrina. 2015. Black Girls: Migrant Domestic Workers and Colonial Legacies. Leiden-Boston: Brill. 
Mbembe, Achille. 2003. "Necropolitics." Public Culture 15 (1): 11-40. doi:10.1215/ 08992363-15-1-11.

Mbembe, Achille. 2005. "La République et sa Bête: à propos des émeutes dans les banlieues de France.” Africultures, December 1.

McClintock, Anne. 1995. Imperial Leather: Race, Gender, and Sexuality in the Colonial Contest. London: Routledge.

McGuinness, Damien. 2016. "Germany Shocked by Cologne New Year Gang Assaults on Women." BBC News, January 5. www.bbc.com/news/world-europe-35231046.

Mezzadra, Sandro, and Brett Neilson. 2013. Border as Methods or the Multiplication of Labor. Durham: Duke University Press.

Mortimer, Caroline. 2016. "Cologne: Three Out of 58 Men Arrested over Mass Sex Attack on New Year's Eve Were Refugees from Syria or Iraq.” The Independent, February 15. www.independent.co.uk/news/world/europe/cologne-only-threeout-of-58-men-arrested-in-connection-with-mass-sex-attack-on-new-years-eveare-a6874201.html.

Mullin, Corinna. 2011. “The US Discourse on Political Islam: Is Obama's a Truly Post-'War-on-Terror' Administration?” Critical Studies on Terrorism 4 (2): 263281.

"Naufragio a sud della Sicilia, almeno 800 morti tra i migranti. Superstiti arrivati a Catania: 'Salvi perchè aggrappati ai morti."' 2015. laRepubblica.it, April 20. http://palermo.repubblica.it/cronaca/2015/04/20/news/naufragio_a_sud_della_ sicilia_morti_tra_700_e_900_migranti_le_salme_a_malta_superstiti_attesi_a_ catania-112381134/.

"Naufragio Lampedusa, oltre 200 migranti morti. 'Disperso gommone con altri 100." 2015. ilfattoquotidiano.it, February 11. www.ilfattoquotidiano.it/2015/02/11/ naufragio-lampedusa-morti-200-migranti-disperso-gommone-100/1414701/.

Navarro, Laura. 2010. "Islamophobia and Sexism: Muslim Women in the Western Mass Media." Human Architecture: Journal of Sociology of Self-Knowledge 8 (2): 95-114. http://scholarworks.umb.edu/humanarchitecture/vol8/iss2/10/.

Puar, Jasbir K. 2007. Terrorist Assemblages: Homonationalism in Queer Times. Durham: Duke University Press.

Pugliese, Joseph. 2010. Biometrics: Bodies, Technologies, Biopolitics. New York: Routledge.

Pugliese, Joseph. 2013. State Violence and Execution of Law: Biopolitical Caesurae of Torture, Black Sites, Drones. Abingdon: Routledge.

Sakai, Naoki. 1997. Translation and Subjectivity: On 'Japan' and Cultural Nationalism. Minneapolis: University of Minnesota Press.

Salerno, Daniele. 2016. "Risky Subjects in Time of Terror: A Semiotic Perspective in the Critical Approaches to Security in Europe." Versus.

Sassu, Vincenzo. 2011. La-Bas La Banlieue. Rivolte, media e immigrazione nel contesto francese. Milano: Mondadori.

Sayyid, Salman S., and AbdoolKarim Vakil, eds. 2010. Thinking Through Islamophobia: Global Perspectives. London: Hurst and Company.

Sharma, Sanjay, and Aswani Sharma. 2003. "White Paranoia: Orientalism in the Age of Empire." Fashion Theory 7 (4): 301-318. doi:10.2752/136270403778051952.

Sim, David. 2015. "Mediterranean Migrant Tragedy: Bodies of Drowned Refugees Arrive in Malta [Photo report]." International Business Times, April 20. http:// www.ibtimes.co.uk/mediterranean-migrant-tragedy-bodies-drowned-refugeesarrive-malta-photo-report-1497329. 
Spivak, Gayatri C. 1988. "Can the Subaltern Speak?." In Marxism and the Interpretation of Culture, edited by Lawrence Grossberg and Cary Nelson, 271313. Urbana: University of Illinois Press.

Syed, Jawad, and Faiza Ali, eds. 2011. “The White Woman's Burden: From Colonial Civilisation to Third World Development.” Third World Quarterly 32 (2): 349-365. doi:10.1080/01436597.2011.560473.

Tyler, Imogen. 2009. “Against Abjection.” Feminist Theory 10 (1): 77-98. doi:10.1177/ 1464700108100393.

Tziovas, Dimitris. 2009. Greek Diaspora and Migration Since 1700: Society, Politics and Culture. Farnham: Ashgate.

Wæver, Ole, Barry Buzan, Morten Kelstrup, and Pierre Lemaitre. 1993. Identity, Migration and the New Security Agenda in Europe. London: Pinter.

Yegenoglu, Meyda. 1998. Colonial Fantasies: Towards a Feminist Reading of Orientalism. Cambridge: Cambridge University Press.

Young, Iris M. 1990. Justice and the Politics of Difference. Princeton, NJ: Princeton University Press. 